\title{
Biology of Artemia persimilis Piccinelli and Prosdocimi, 1968 in a hypersaline lake in a semiarid protected area (Parque Luro Reserve, La Pampa, Argentina)
}

\author{
Alicia M. Vignatti*, Candela Capecce, Gabriela C. Cabrera and Santiago A. Echaniz \\ Facultad de Ciencias Exactas y Naturales, Universidad Nacional de La Pampa. Avenida Uruguay 151, 6300, \\ Santa Rosa, La Pampa. República Argentina. \\ * Corresponding author: aliciavignatti@cpenet.com.ar
}

Received: 09/07/18 Accepted: 03/05/19

\begin{abstract}
Biology of Artemia persimilis Piccinelli and Prosdocimi, 1968 in a hypersaline lake in a semiarid protected area (Parque Luro Reserve, La Pampa, Argentina)
\end{abstract}

Artemia persimilis is the only species of the genus that is native to South America. Its biology has been studied in lakes in the arid diagonal in Argentina, which are affected by agricultural and livestock activities. The aim was to study biological aspects and their relations with environmental variables in a protected lake under conditions similar to those that existed before the increase in human influence on this area. From October 2014 to September 2015, samples were taken monthly from Este Lake $\left(64^{\circ} 11^{\prime} 04^{\prime \prime} \mathrm{W}, 36^{\circ} 55^{\prime} 18^{\prime \prime} \mathrm{S}\right)$, which is in the intangible zone of Parque Luro Provincial Reserve. In situ water temperature, dissolved oxygen, water transparency, and $\mathrm{pH}$ were determined, and two quantitative zooplankton samples were taken. The maximum depth varied between 0.9 and $0.33 \mathrm{~m}$, the mean salinity was $262.17 \mathrm{~g} / \mathrm{L}( \pm 43.87)$, and $\mathrm{Na}^{+}$and $\mathrm{Cl}^{-}$predominated. The water transparency was $0.56 \mathrm{~m}( \pm 0.21)$, and the concentration of phytoplankton chlorophyll- $a$ was $6.19 \mathrm{mg} / \mathrm{m}^{3}( \pm 8.17)$. The mean density and biomass of $A$. persimilis were 209.31 ind./L $( \pm 214.04)$ and $7535.10 \mu \mathrm{g} / \mathrm{L}( \pm 12376.57)$, respectively, which exceeded those recorded in other lakes in the region. Nauplii and metanauplii were registered in every month except December and July, and they showed high percentages of total density. A correlation was found between density and temperature but not between density and salinity, which could indicate that the range in Este Lake is optimal for the species. Although it is difficult to prevent colonization by exotic anostracan species by zoochory, the existence of an abundant population of $A$. persimilis in a protected lake in the central Argentinean region is an optimal opportunity for the conservation of this species.

Key words: Artemia persimilis, Artemia franciscana, biological invasions, Argentinian Central Pampa, hypersaline lake

\section{RESUMEN}

\section{Biología de Artemia persimilis Piccinelli y Prosdocimi, 1968 en un lago hipersalino de un área protegida del centro semiárido de Argentina}

Artemia persimilis es la única especie del género nativa de Sudamérica. Su biología se ha estudiado en lagos de la diagonal árida Argentina relativamente impactados por la explotación agrícola y ganadera. El objetivo fue estudiar aspectos biológicos y sus relaciones con parámetros ambientales en un lago protegido, en condiciones similares a las existentes antes del aumento de la influencia humana. Se tomaron muestras mensuales entre octubre de 2014 y septiembre de 2015 en el lago Este (64 11 ' $\left.04^{\prime \prime} \mathrm{W}, 36^{\circ} 55^{\prime} 18^{\prime \prime} \mathrm{S}\right)$, en la zona intangible de la Reserva Provincial Parque Luro. In situ se determinaron la temperatura del agua, oxígeno disuelto, transparencia, pHy se tomaron dos muestras cuantitativas de zooplancton. La profundidad varió entre 0.9 y $0.33 \mathrm{~m}$, la salinidad media fue $262.17 \mathrm{~g} / \mathrm{L}$ ( \pm 43.87) y predominaron el $\mathrm{Na}^{+}$y $\mathrm{Cl}^{-}$. La transparencia fue $0.56 \mathrm{~m}( \pm 0.21)$ y la concentración de clorofila-a fitoplanctónica fue $6.19 \mathrm{mg} / \mathrm{m}^{3}( \pm 8.17)$. La densidad y biomasa media de A. persimilis fueron $209.31 \mathrm{ind} . / \mathrm{L}$ ( \pm 214.04$)$ y $7535.10 \mu \mathrm{g} / \mathrm{L}$ ( \pm 12 376.57) y superaron las registradas en otros lagos de la región. Excepto en diciembre y julio, siempre se registraron nauplios y metanauplios, que representaron porcentajes elevados de la densidad total. Se encontró correlación entre la densidad y la temperatura pero no con la salinidad, lo que podría deberse a que el rango de ésta en el lago Este es óptimo para el desarrollo de la especie. Aunque es difícil prevenir la colonización mediante zoocoria 
por alguna especie de anostraco exótica, la existencia de la población de A. persimilis más abundante del centro de Argentina en un lago protegido representa una oportunidad óptima para la conservación de esta especie.

Palabras clave: Artemia persimilis, Artemia franciscana, invasiones biológicas, Pampa Central Argentina, lago hipersalino

\section{INTRODUCTION}

Many saline lakes (salinity $>3 \mathrm{~g} / \mathrm{L}$ ) exist in the arid diagonal that crosses Argentina from north to south (D'Ambrosio et al., 2016). These lakes, which range widely in salinity, are abundant in the central portion of the arid diagonal where the Dry Pampas region is located (Echaniz \& Vignatti, 2017). Because the water in most of these lakes comes from rainfall or groundwater discharge, they can remain dry for variable periods from a few months to several years, which are strongly related to the short-term cycles of precipitation and drought cycles caused by El Niño and La Niña events (Viglizzo, 2010). The loss of water occurs mainly through evaporation, which causes marked changes in water levels during hydroperiods and produces wide fluctuations in salinity (Echaniz \&Vignatti, 2017; Echaniz et al., 2006; Vignatti et al., 2012).

Hypersaline lakes have a salinity $>50 \mathrm{~g} / \mathrm{L}$ (Hammer, 1986), which generates strong environmental stress (Herbst, 2001). These lakes have high biological productivity but low diversity (Amat et al., 2007), which is restricted to organisms that have physiological mechanisms that are capable of withstanding osmotic stress (Gajardo $\&$ Beardmore, 2012). The most conspicuous of these organisms are the anostracans of the Artemia genus, which is dominant in the zooplankton community. These organisms are among the most exposed to the damaging effects of habitat loss and the entry of invasive species, which was previously recorded in hypersaline habitats in the Mediterranean basin (Amat et al., 2007).

Two species have been recorded in Argentina: Artemia franciscana Kellogg, 1906 and A. persimilis Piccinelli and Prosdocimi, 1968 (Cohen, 1998; Vignatti et al., 2017; Echaniz \& Vignatti, 2017). Artemia franciscana is exotic, and it entered the country by cysts transported by migratory birds from the northern hemisphere (Muñoz et al., 2013), which allowed its expan- sion to $31^{\circ} \mathrm{S}$ (Bucher, 2006; Pilati et al., 2016). Artemia persimilis is autochthonous and restricted to Chile and Argentina (Clegg \& Gajardo, 2009). It is the only species registered in the province of La Pampa (Vignatti et al., 2014; Echaniz et al., 2015; Echaniz \& Vignatti, 2017; Vignatti et al., 2017).

Artemia franciscana exhibits attributes that characterize an invasive species, such as a large native range, a short generation time, single female colonization, a high dispersal rate, among others (Speer \& Weider, 2018). Previous research indicated that this species could be in evolutionary expansion because of its ability to colonize (Clegg \& Gajardo, 2009). These characteristics have enabled this species to monopolize many aquatic ecosystems around the world (Muñoz $e t$ al., 2014), thus displacing native species (Green et al., 2005). In Argentina, A. franciscana's lower tolerance of low temperatures could limit its spread toward the south of the country (Amat $e t$ al., 2004; Vignatti et al., 2014). Hence, the present study's focus on the saline lakes located between $33^{\circ}$ and $37^{\circ} \mathrm{S}$, in the transition zone between the distributions of $A$. franciscana and $A$. persimilis, is relevant to aquatic saline ecosystems both in this area and worldwide.

The Artemia species is important economically because it is grown as a live food in aquaculture (Sorgeloos et al., 1986; Dhont \& Sorgeloos, 2002; Rodríguez-Canché et al., 2006; Ben Naceur et al., 2008). Some aspects of the biology of A. persimilis have been studied in the laboratory (Pastorino et al., 2002; Sato et al., 2004; Medina et al., 2007; Mechaly et al., 2004, 2013). However, information about their biology under natural conditions is relatively scarce. Most data on this species were collected in studies conducted in hypersaline lakes in the central semiarid region of Argentina, which are affected by the agricultural and livestock exploitation carried out in their basins (Vignatti et al., 2014; 2017; Echaniz et al., 2015). 
A hypersaline lake surrounded by natural vegetation in the intangible zone of the extensive protected area, the Parque Luro Provincial Reserve, offers an excellent opportunity to study the biological aspects of $A$. persimilis in conditions of low anthropogenic influence. The objective of this work is to analyze the population characteristics of the species (i.e., density, biomass, and size) and their relationships with the main limnological variables over an annual cycle in conditions similar to those that the hypersaline ecosystems of the region could have had before the increase in human influence by the deforestation of large areas for growing cereals and oilseeds and raising livestock. The results of the present study are compared with those obtained in other hypersaline environments previously studied in the region, such as the Utracán, La Amarga, and Guatraché Lakes, which are subject to much greater anthropogenic influence.

\section{MATERIALS AND METHODS}

\section{Study area}

The Parque Luro Provincial Reserve is located in the eastern-central area of the province of $\mathrm{La}$ Pampa (Fig. 1) in the phytogeographic region of the Thorny Forest (Oyarzábal et al., 2018) where caldén (Prosopis caldenia Burkart) predominates. It has an area of 7607 ha, which is covered by natural vegetation, in which agricultural activities and deforestation have not occurred for more than 70 years (González-Roglich et al., 2012).

The average annual rainfall (determined in Ataliva Roca, the town closest to the reserve) is around $700 \mathrm{~mm} / \mathrm{yr}$ (APA, 2018). However, the rains are highly variable because they are influenced by El Niño and La Niña events (Viglizzo, 2010; Russián et al., 2015). The distribution of rainfall throughout the year has shown higher peaks in October and March (Cano, 1980). In this area, evapotranspiration greatly exceeds the rainfall (an average of $800 \mathrm{~mm} / \mathrm{yr}$ ) (Roberto et al., 1994).

The northern part of the reserve is crossed by one of the deep west-southwest to east-northeast transversal valleys that characterize the eastern-central region of La Pampa (Lorenzo et
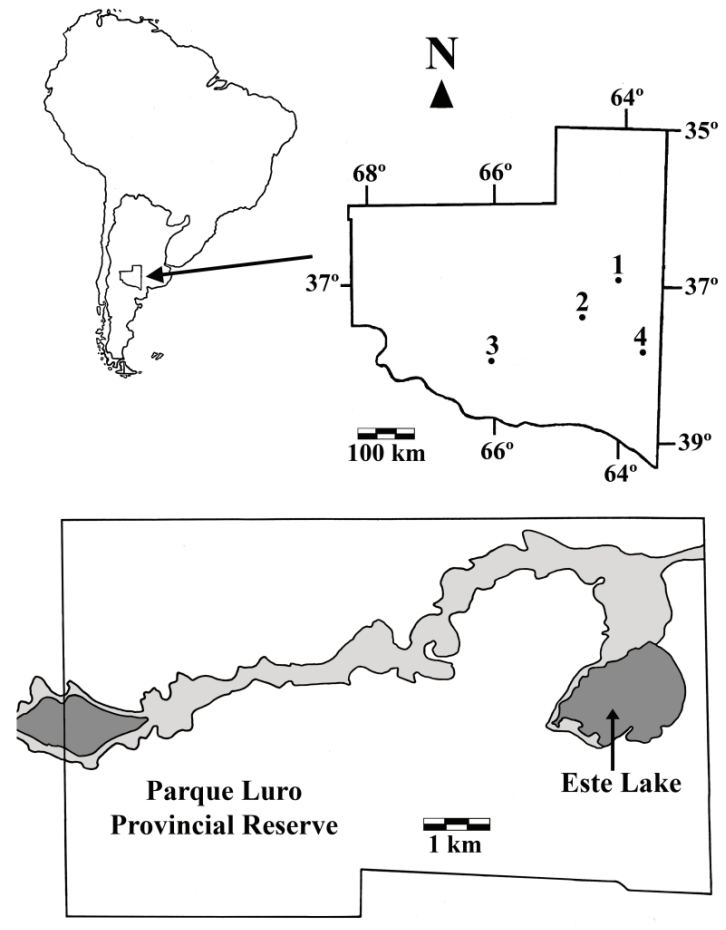

Figure 1. Above: Geographical location of the hypersaline lakes studied in the semiarid Argentinean Central Pampas. 1: Parque Luro Este Lake (64 $11^{\prime} 04^{\prime \prime}$ W, $36^{\circ} 55^{\prime} 18^{\prime \prime}$ S). 2: Utracán Lake (64 $35^{\prime} 56^{\prime \prime} \mathrm{W}, 37^{\circ} 16^{\prime}$ 59" S). 3: La Amarga Lake (66 06' $27^{\prime \prime}$ W, $38^{\circ} 13^{\prime} 20^{\prime \prime}$ S). 4: Guatraché Lake (633 $31^{\prime} 28^{\prime \prime}$ W, 37 44' $19^{\prime \prime}$ S). Below: Location of Este Lake in the Parque Luro Provincial Reserve. The external line indicates the limits of the Reserve. Dark gray: lakes. Light gray: areas of the basin that flood very occasionally. Arriba: Ubicación geográfica de los lagos hipersalinos estudiados en la Pampa central semiárida de Argentina. 1: Lago Este de Parque Luro (64 $\left.11^{\prime} 04^{\prime \prime} \mathrm{W}, 36^{\circ} 55^{\prime} 18^{\prime \prime} \mathrm{S}\right)$. 2: Laguna Utracán (64 $\left.35^{\prime} 56^{\prime \prime} \mathrm{W}, 37^{\circ} 16^{\prime} 59^{\prime \prime} \mathrm{S}\right)$. 3: Laguna La Amarga (66 $\left.06^{\prime} 27^{\prime \prime} \mathrm{W}, 38^{\circ} 13^{\prime} 20^{\prime \prime} \mathrm{S}\right)$. 4: Laguna Guatraché $\left(63^{\circ} 31^{\prime} 28^{\prime \prime} \mathrm{W}, 37^{\circ} 44^{\prime} 19^{\prime \prime} \mathrm{S}\right)$. Abajo: Ubicación del lago Este en la Reserva Provincial Parque Luro. El trazo externo indica los límites de la Reserva. Gris oscuro: lagunas. Gris claro: áreas de la cuenca que se inundan muy ocasionalmente.

al., 2013). Este Lake (64 $11^{\prime}$ '04" W, 36 $56^{\circ}$ ' $18^{\prime \prime}$ $\mathrm{S})$ is located in this valley near the eastern limit of the Reserve in the zone of restricted access. This shallow temporary lake is fed by rainfall, surface runoff, and groundwater. It has no effluents, and the main water losses are through evaporation or infiltration during dry periods. During the study, Este Lake had a maximum length of $1708 \mathrm{~m}$, a maximum width of $1056 \mathrm{~m}$, and a maximum surface area of 132 ha (Fig. 1). 


\section{Field and laboratory work}

From October 2014 to September 2015, samples were taken monthly at two sites in the lake. At each site, the water temperature, dissolved oxygen concentration (Lutron ${ }^{\circledR}$ OD 5510 oximeter), water transparency (22 cm diameter Secchi disk), and $\mathrm{pH}$ (Corning ${ }^{\circledR}$ PS $15 \mathrm{pH}$ meter) were determined. Two quantitative zooplankton samples were taken. Because of the shallow depth, graduated pails were used to take samples by integrating the water column and then filtering through a net with a mesh size of $40 \mu \mathrm{m}$. A qualitative sample was also taken using a similar net. All samples were anesthetized with $\mathrm{CO}_{2}$ and kept refrigerated until fixation. Subsequently, they were deposited in the collection at the Universidad Nacional de La Pampa. In addition, water samples were taken and kept refrigerated until laboratory analysis. The salinity was determinate by the gravimetric method by drying at $104{ }^{\circ} \mathrm{C}$ (APHA, 1992). The concentration of chlorophyll- $a$ was determined through extraction with aqueous acetone and spectrophotometry (Arar, 1997). The concentrations of organic suspended solids (OSS), and inorganic suspended solids (ISS) were determined by weighing Microclar FFG047WPH filters after drying at $103{ }^{\circ} \mathrm{C}-105$ ${ }^{\circ} \mathrm{C}$ to a constant weight and then calcining at 550 ${ }^{\circ} \mathrm{C}$ (EPA, 1993). On two occasions (January and October), water samples were taken to determine the ionic composition according to standardized routines: $\mathrm{Na}^{+}$(selective ion electrode); $\mathrm{K}^{+}$(determination of the intensity of the turbidity by the combination of potassium with sodium tetraphenylborate); $\mathrm{Ca}^{2+}$ (EDTA digital titulometric method or spectrophotometric method for very low calcium levels); $\mathrm{Mg}^{2+}$ (digital titrometric method or spectrophotometric method for very low magnesium levels); $\mathrm{Cl}^{-}$(argentometric method [digital titration with silver nitrate solution in the presence of potassium chromate] or the spectrophotometric method for very low concentrations); $\mathrm{SO}_{4}{ }^{2-} \quad$ (spectrophotometric determination of the intensity of the turbidity formed during the reaction of the sulfate with barium); and $\mathrm{HCO}_{3}{ }^{-}$and $\mathrm{CO}_{3}{ }^{2-}$ (alkalinity method of phenolphthalein and digital titration) (APHA, 1992).

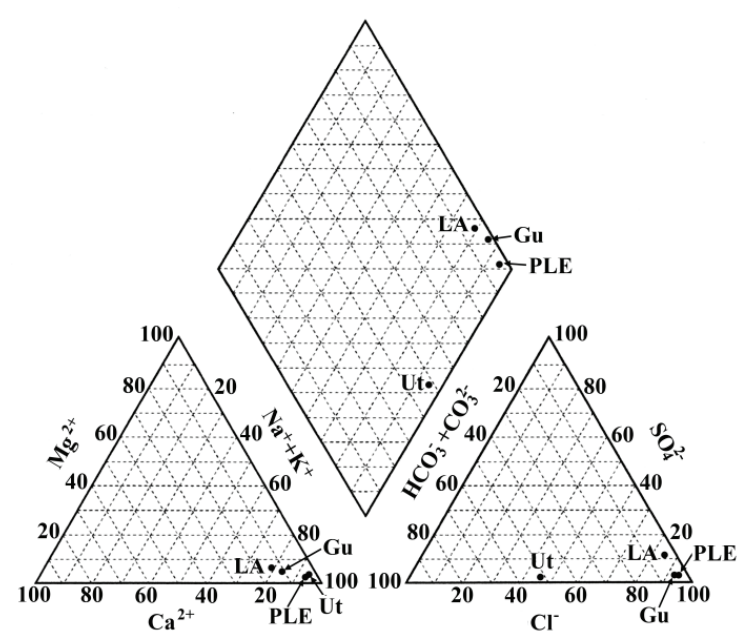

Figure 2. Comparison of the ionic composition of the water of the four-hypersaline lakes studied in the semiarid Argentinean Central Pampas. LA: La Amarga Lake. Gu: Guatraché Lake. PLE: Parque Luro Este Lake. Ut: Utracán Lake. Comparación de la composición iónica del agua de los cuatro lagos hipersalinos estudiados en la en la Pampa central semiárida de Argentina. LA: La Amarga. Gu: Guatraché. PLE: Parque Luro Este. Ut: Utracán.

The Artemia counts in the complete sample were performed under stereoscopic microscopy in Bogorov and Sedgwick-Rafter chambers. Density was expressed as ind./L.

The proportions of the different stages (Cohen et al., 1999) were determined under an optical microscope in Sedgwick-Rafter chambers. To estimate the biomass, conventional measurements of 100 specimens per sample were taken using an optical microscope with a micrometric Arcano 10x eyepiece. The formulas that related the total length to the dry weight of $A$. franciscana (Wurtsbaugh, 1992) were used. Measurements were performed on all specimens present in the sample at a low density ( $<100$ specimens).

We used the classification of continental waters based on salinity, as proposed by Hammer (1986). When average values were presented, we used standard deviation (SD) as the error measure. To examine the relations between all environmental factors and zooplankton attributes, Spearman correlation coefficients $\left(\mathrm{r}_{\mathrm{s}}\right)$ were calculated (Sokal \& Rohlf, 1995; Zar, 1996). We used the Past (Hammer et al., 2001) and Infostat (Di Rienzo et 
al., 2010) software packages. All applicable international, national, and institutional guidelines for the care and use of animals were followed.
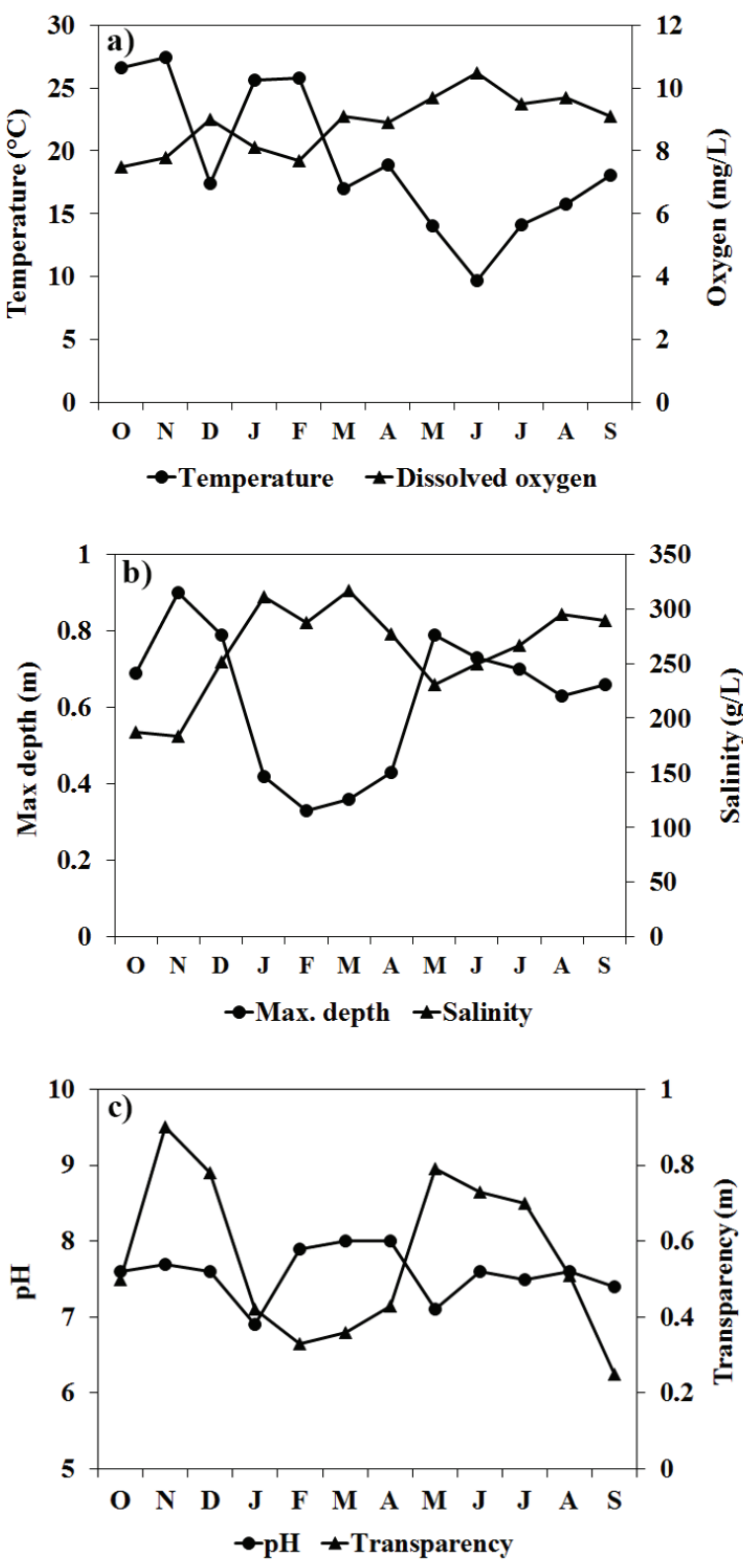

Figure 3. Monthly variations in (a) water temperature and dissolved oxygen, (b) maximum depth and salinity, and (c) $\mathrm{pH}$ and water transparency between October 2014 and September 2015 in Parque Luro Este Lake. Variación mensual de (a) temperatura del agua y oxígeno disuelto, (b) profundidad máxima y salinidad y (c) pH y transparencia del agua del lago Este de Parque Luro entre octubre de 2014 y septiembre de 2015.

\section{RESULTS}

The ionic composition showed the predominance of $\mathrm{Cl}^{-}\left(96.80 \%\right.$ of anions) and $\mathrm{Na}^{+}(94.9 \%$, of cations) (Fig. 2). The water temperature followed a seasonal pattern with a minimum in June and a maximum in November. In December, the temperature dropped because of the entry of rainwater, but it then rose rapidly (Fig. 3a). The concentration of dissolved oxygen was relatively high and variable (Fig. 3a) in correlation with the water temperature $\left(\mathrm{r}_{\mathrm{s}}=-0.95, p<0.05\right)$. The depth of the lake was low, and a great loss of water by evaporation was observed in summer. However, in March, the water level was increased by seasonal rainfall (Fig. 3b). The salinity was high during the entire study period in correlation with the depth of the lake $\left(\mathrm{r}_{\mathrm{S}}=-0.81 ; p<0.05\right)$ (Fig. 3b). The $\mathrm{pH}$ was relatively stable, ranging between 6.9 and 8.0 (Fig. 3c). The water transparency ranged between $0.25 \mathrm{~m}$ in September and $0.9 \mathrm{~m}$ in November (Fig. 3c). No significant correlations were found between transparency and the other environmental variables. With the exception of two peaks in August and September, the phytoplankton chlorophyll- $a$ concentration did not exceed $3 \mathrm{mg} / \mathrm{m}^{3}$ (Fig. 4). During the study, ISS represented the highest proportion of suspended solids ( $81 \%$ of the total) (Fig. 4), and a significant correlation was found between the OSS concentration and that of chlorophyll- $a\left(\mathrm{r}_{\mathrm{s}}=\right.$ $0.8 ; p<0.05)$.

The mean density of the $A$. persimilis population throughout the study was 209.31 ind./L ( \pm 214.04); minimum density occurred in July, and maximum density occurred in April (Fig. 5). The mean density showed a significant correlation with water temperature only $\left(\mathrm{r}_{\mathrm{s}}=0.57 ; p<0.05\right)$. The total mean biomass was $7535.10 \mu \mathrm{g} / \mathrm{L}( \pm 12$ 376.57), with a minimum in March and a maximum in November (Fig. 5). No correlations were found between the Artemia biomass and any environmental variable.

The first stages (nauplii and metanauplii) were verified in every month except December and July when only post-metanauplii, post-larvae, and adults were observed. Nauplii represented high percentages of population density in February and March (Fig. 6a), but their abundance was relative- 


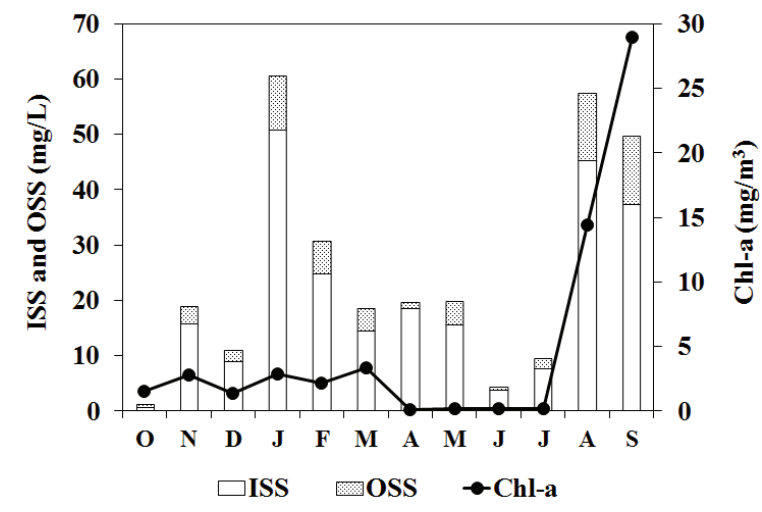

Figure 4. Monthly variations in ISS, OSS, and chlorophyll- $a$ concentrations between October 2014 and September 2015 in Parque Luro Este Lake. Variación mensual de la concentración de ISS, OSS y clorofila-a en el lago Este de Parque Luro entre octubre de 2014 y septiembre de 2015.

ly low in the remaining samples. Metanauplii were the dominant stage on five occasions, when they exceeded $40 \%$ of the population density (Fig. 6a). Positive significant correlations were obtained between the density of nauplii and metanauplii and water temperature $\left(\mathrm{r}_{\mathrm{S}}=0.61 ; p<\right.$ 0.05 and $\mathrm{r}_{\mathrm{s}}=0.57 ; p<0.05$, respectively).

With the exception of February, the most frequent stage was post-metanauplii, which showed in high percentages of the population in most samples. A peak occurred in April when 78 $\%$ of the population was comprised of post-metanauplii (Fig. 6a). The most advanced stages (post-larvae and adults) were not recorded in October and March, and in the remaining months, they showed relatively low densities. Post-larvae dominated only in September $(32 \%$ of the total population density), and the adult stage was never dominant (Fig. 6a). The group composed of post-larvae and adults comprised the highest biomass percentage of the population on nine occasions (Fig. 6b) because of their larger size (some adults reached $10.12 \mathrm{~mm}$ ). This contribution was highest in November when they reached $13 \%$ and $82 \%$ of the population biomass. When post-larvae and adults were not registered, the less developed stages reflected the highest biomass, such as in October, when metanauplii reached $48 \%$ of the total, or in March, when the

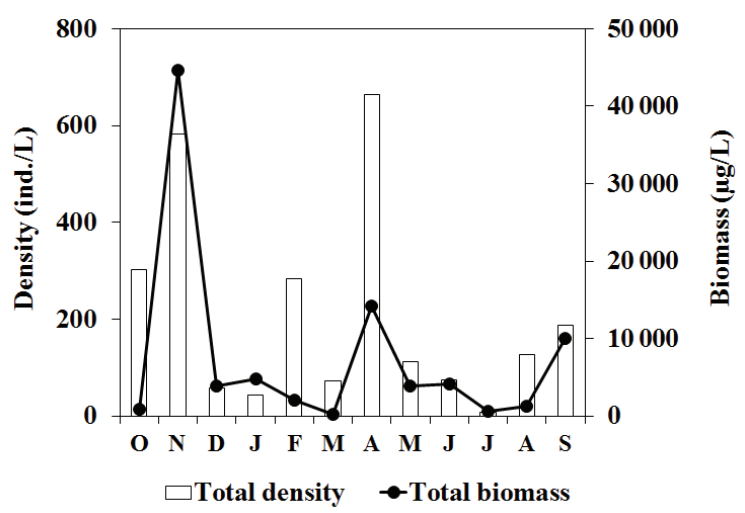

Figure 5. Monthly variations in Artemia persimilis density and biomass between October 2014 and September 2015 in Parque Luro Este Lake. Variación mensual de la densidad y biomasa totales de Artemia persimilis del lago Este de Parque Luro entre octubre de 2014 y septiembre de 2015.

nauplii represented the $70 \%$ of the population biomass. In contrast, in August, all stages were found, and post-metanauplii contributed the highest biomass, reaching $592.05 \mu \mathrm{g} / \mathrm{L}$ (45 \% of the population biomass) (Fig. 6b).

\section{DISCUSSION}

The results showed that the salinity of Parque Luro Este Lake was similar to that of other hypersaline lakes in the semiarid Central Pampas where $A$. persimilis was detected (Table 1), such as La Amarga Lake (Echaniz et al., 2015; Echaniz \& Vignatti, 2017), Utracán Lake (Vignatti et al., 2017), and Guatraché Lake, where A. persimilis was recorded when the salinity reached 418.5 $\mathrm{g} / \mathrm{L}$, which is the maximum salinity in which this species has been found in natural waters (Vignatti et al., 2014).

Similar to most lakes in the semiarid Central Pampas, Este Lake depends on seasonal rains (Cano, 1980) that highly fluctuate interannually (Viglizzo, 2010; Russián et al., 2015). This explains the changes in certain lake variables, such as the depth, which reached the maximum in November and then fell sharply, or salinity, which showed variations higher than $130 \mathrm{~g} / \mathrm{L}$ during the study period. This result is similar to that recorded in the aforementioned hypersaline 
Table 1. Main limnological variables, total density, and biomass of Artemia persimilis and stage densities (mean values) in saline lakes in the semiarid Central Pampas where the species was recorded. Valores de las principales variables limnológicas, densidad y biomasa totales de A. persimilis y densidad de los diferentes estadios (valores medios) en los lagos de la Pampa central semiárida en los que la especie fue registrada.

\begin{tabular}{lcccc}
\cline { 2 - 4 } & $\begin{array}{c}\text { La Amarga } \\
\mathbf{( 2 0 0 7 )}\end{array}$ & $\begin{array}{c}\text { Utracán } \\
\mathbf{( 2 0 0 9 - 2 0 1 0 )}\end{array}$ & $\begin{array}{c}\text { Guatraché } \\
\mathbf{( 2 0 1 1 - 2 0 1 2})\end{array}$ & Parque Luro Este \\
\hline Water temperature ( $\left.{ }^{\circ} \mathbf{C}\right)$ & $14.58 \pm 7.99$ & $16.53 \pm 7.61$ & $23.78 \pm 10.87$ & $19.20 \pm 5.81$ \\
Salinity (g/L) & $115.51 \pm 19.02$ & $238.05 \pm 92.34$ & $345.40 \pm 48.25$ & $262.17 \pm 43.87$ \\
pH & $7.82 \pm 0.53$ & $9.21 \pm 0.09$ & $7.73 \pm 0.23$ & $7.58 \pm 0.33$ \\
Transparency (m) & $1.54 \pm 0.15$ & $0.11 \pm 0.06$ & $>0.2$ & $0.56 \pm 0.21$ \\
Chlorophyll- $\boldsymbol{a}$ (mg/m) & $1.65 \pm 1.16$ & $39.16 \pm 22.69$ & $8.39 \pm 6.97$ & $4.84 \pm 8.53$ \\
Dissolved oxygen (mg/L) & $6.83 \pm 1.23$ & $8.11 \pm 3.07$ & $\mathrm{~N} / \mathrm{D}$ & $8.88 \pm 0.93$ \\
Total density (ind./L) & $1.56 \pm 2.17$ & $56.98 \pm 106.64$ & $9.60 \pm 16.12$ & $209.31 \pm 214.04$ \\
Nauplii density (ind./L) & $0.46 \pm 0.63$ & $11.59 \pm 33.68$ & $2.15 \pm 1.12$ & $39.50 \pm 54.49$ \\
Metanauplii density (ind./L) & $0.82 \pm 1.35$ & $16.10 \pm 38.54$ & $1.22 \pm 1.50$ & $63.31 \pm 77.51$ \\
Post-metanauplii density (ind./ L) & $0.08 \pm 0.08$ & $22.87 \pm 43.04$ & $5.77 \pm 11.80$ & $74.22 \pm 142.80$ \\
Post-larvae density (ind./L) & $0.14 \pm 0.16$ & $3.78 \pm 6.48$ & $1.08 \pm 1.57$ & $24.93 \pm 20.07$ \\
Adults density (ind./L) & $0.05 \pm 0.06$ & $2.73 \pm 3.95$ & $1.30 \pm 2.05$ & $15.30 \pm 26.03$ \\
Total biomass ( $\boldsymbol{\mu g} / \mathbf{L})$ & $122.43 \pm 99.33$ & $1230.10 \pm 1353.69$ & 346.11 & $7535.10 \pm 12376.57$ \\
\hline & & & & \\
\hline
\end{tabular}

lakes: in La Amarga, salinity varied in a range of $46 \mathrm{~g} / \mathrm{L}$; in Guatraché, it was almost $140 \mathrm{~g} / \mathrm{L}$; and in Utracán, it was $325 \mathrm{~g} / \mathrm{L}$ (Echaniz et al., 2015; Vignatti et al., 2014, 2017).

The predominance of $\mathrm{Na}^{+}$and $\mathrm{Cl}^{-}$in Este Lake is similar to most shallow lakes previously studied in the semiarid Central Pampas (Echaniz \& Vignatti, 2017). This ionic composition indicates that the mechanisms that control the water chemistry of Este Lake involve evaporation and crystallization, which are typical processes in arid or semiarid regions where the evapotranspiration rates are higher than the precipitation rates (Gibbs, 1970; Wetzel, 2001; Kalff, 2002). The $\mathrm{pH}$ of Este Lake was slightly alkaline and similar to that of La Amarga and Guatraché Lake (Echa- niz et al., 2015; Vignatti et al., 2014), but it was considerably lower than that of Utracán Lake. This could have been due to the latter's relatively high amounts of $\mathrm{CO}_{3}{ }^{2-}$ and $\mathrm{HCO}_{3}$ - (Fig. 2) from the discharge of groundwater enriched with these ions, and which are stored in the sediments of the Cerro Azul geological formation (Malán, 2007).

The findings of this study showed that the transparency of the water was always high, reaching the bottom in most of the study period, which could be attributed to the reduced concentrations of chlorophyll- $a$ and TSS.

A feature that distinguishes the protected Este Lake $A$. persimilis population is the high mean density, which in this study greatly exceeded the densities previously recorded in other lakes. The 
minimum salinity of Guatraché Lake coincided with the maximum value measured in Este Lake. The greater salinity of the latter could be a limiting environmental factor for $A$. persimilis in that lake (Vignatti et al., 2014) because high environmental stress could cause more energy to be allocated to osmoregulation than to reproduction (Gajardo \& Beardmore, 2012). The mean salinity of Utracán Lake was relatively similar to that of Este Lake, but salinities higher than $300 \mathrm{~g} / \mathrm{L}$ were recorded on occasions when A. persimilis was not registered (Vignatti et al., 2017).

The lack of correlation between $A$. persimilis density and salinity in Este Lake, where the greatest number of individuals was found, could indicate that the salinity range of Este Lake is the best for the development of the species (Vignatti et al., 2014).

As in other Central Pampas lakes, in Este Lake the total density was positively influenced by temperature. The abundance of nauplii and metanauplii was higher in the months of higher temperatures, which would indicate a high reproductive rate by the production of subitaneous eggs. Although post-metanauplii, post-larvae, and adults predominated, nauplii were also recorded during the winter months, which coincided with the results found in Utracán Lake, where a high proportion of juvenile stages with temperatures barely above $3{ }^{\circ} \mathrm{C}$ were recorded. This finding could indicate that $A$. persimilis reproduction continued despite the low temperature, which could be an effective defense against possible invasions by its congeneric, $A$. franciscana .

The mean biomass of $A$. persimilis in Este Lake was considerably higher than that in $\mathrm{La}$ Amarga, Guatraché and Utracán Lakes, and it was related to the size of the organisms. The group composed of post-larvae and adults were the greatest proportion of the total population biomass on most occasions. Exceptions were in October and March, when the most advanced stages were not recorded, and metanauplii and nauplii represented the highest biomass.

Many saline lakes in the central region of Argentina are influenced by anthropogenic activity, especially agriculture and livestock. This activity has resulted in increased nutrient concentrations in water, sediment, which has changed
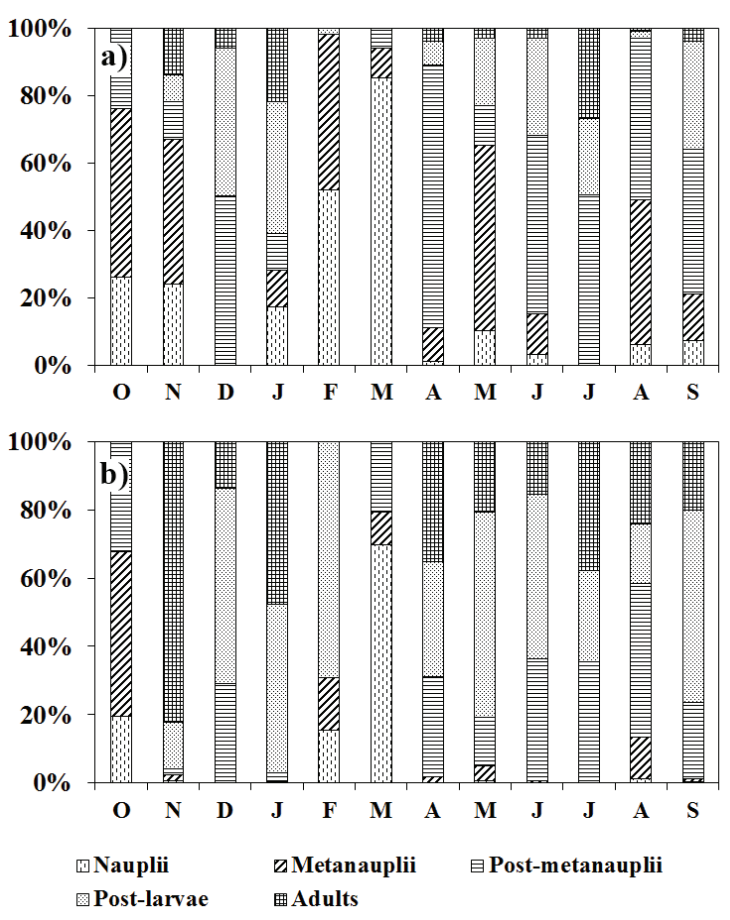

Figure 6. Monthly variations in contributions of the different stages to the total (a) density and (b) biomass of $A$. persimilis population. Variación mensual de la contribución relativa de los diferentes estadios a (a) la densidad y (b) la biomasa total de la población de A. persimilis.

the original characteristics of the lakes (Echaniz \& Vignatti, 2017). The loss of environments suitable for the development of autochthonous species is a factor that damages global biodiversity and may lead to the loss of Artemia species (Amat et al., 2007).

The existence of a hypersaline lake in the intangible sector of a protected area where the most abundant $A$. persimilis population of the central region of Argentina has been recorded offers an opportunity for the conservation of this species. The restrictions to access and human activities in the Este Lake basin can prevent environmental deterioration and minimize the risk of the anthropogenic introduction of non-native zooplankton species. The latter is a phenomenon that has already occurred in central Argentina, where the introduction and rapid dispersion of the Old World cladoceran Moina macrocopa (Straus, 1820) (Paggi, 1997; Vignatti et al., 2013) has 
been recorded. However, the presence in Este Lake of waterfowl, such as the flamingo Phoenicopterus chilensis Molina, 1782 (per. obs.), represents a potential risk for the introduction of A. franciscana. This invasion is difficult to avoid because zooplankton is included in the diet of these birds, which are widely distributed in South America and have long migratory routes (De los Ríos Escalante, 2015; Polla et al., 2018). Thus, it is currently difficult to anticipate any measure to prevent or eradicate the exotic brine shrimp species because the arrival of waterfowl cannot be prevented, and the oviparism mode of reproduction in Artemia ensures its persistence in any colonized ecosystem (Amat et al., 2007).

Although a possible limitation of the advance of A. franciscana to the south is its lower tolerance of low temperatures (Amat et al., 2004; Vignatti et al., 2014), the phenomenon of global warming, which has been verified in Argentina (Barros et al., 2015), could change this situation drastically. A small increase in the average water temperature of the saline lakes in the Central Pampas would allow A. franciscana to colonize ecosystems located farther south than its current distribution, which could result in the local extinction of the native species $A$. persimilis (Vignatti et al., 2017).

\section{ACKNOWLEDGEMENTS}

We thank Lic. Fabián Tittarelli, Secretary of Ecology of the Government of the Province of La Pampa, for allowing access to Este Lake, the National University of La Pampa, for the partial financial support of the project, and the anonymous reviewers who helped us to improve this manuscript.

\section{REFERENCES}

AMAT, F., R. COHEN, F. HONTORIA \& C. NAVARRO. 2004. Further evidence and characterization of Artemia franciscana (Kellogg, 1906) populations in Argentina. Journal of Biogeography, 31: 1735-1749.

AMAT, F., F. HONTORIA, J. C. NAVARRO, N. VIEIRA \& G. MURA. 2007. Biodiversity loss in the genus Artemia in the Western Mediter- ranean Region. Limnetica, 26 (2): 387-404. APA (Administración Provincial del Agua). 2018. Registro de precipitaciones medias mensuales. APHA. 1992. Standard Methods for the Examination of Water and Wastewater. 18th edition. American Public Health Association (APHA), American Water Works Association (AWWA) and Water Pollution Control Federation (WPCF). Washington, DC.

ARAR, E. J. 1997. In Vitro Determination of Chlorophylls a, b, c $+\mathrm{c}$ and Pheopigments in Marine and Freshwater Algae by Visible Spectrophotometry. Method 446.0. U.S. Environmental Protection Agency.

BARROS, V., J. BONINSEGNA, I. CAMILLONI, M. CHIDIAK, G. MAGRÍN \& M. RUSTICUCCI. 2015 Climate change in Argentina: Trends, projections, impacts and adaptation. WIREs Climate Change, 6(2): 151-169. DOI: 10.1002/wcc.316

BEN NACEUR, H., A. BEN REJEB JENHANI, M. EL CAFSI \& M. SALAH ROMDHANE. 2008. Determination of biological characteristics of Artemia salina (Crustacea: Anostraca) population from Sabkhet Sijoumi (NE Tunisia). Transitional Waters Bulletin, 3: 65-74. DOI: $10.1285 / \mathrm{i} 1825229 \mathrm{Xv} 2 \mathrm{n} 3 \mathrm{p} 65$

BUCHER, E. (Ed.). 2006. Bañados del río Dulce y laguna Mar Chiquita (Córdoba, Argentina). Academia Nacional de Ciencias. Córdoba. Argentina.

CANO, E. (coord.). 1980. Inventario Integrado de los Recursos Naturales de la provincia de La Pampa. Instituto Nacional de Tecnología Agropecuaria, Provincia de La Pampa y Universidad Nacional de La Pampa. Buenos Aires. Argentina.

CLEGG, J. S. \& G. GAJARDO. 2009. Two highly diverged New World Artemia species, A. franciscana and $A$. persimilis, from contrasting hypersaline habitats express a conserved stress protein complement. Comparative biochemistry and physiology. Part A, Molecular \& integrative physiology, 153: 451-456. DOI: 10.1016/j.cbpa.2009.04.613

COHEN, R. 1998. Anostraca. En: Biodiversidad de Artrópodos Argentinos. S. Coscarón \& J. J. Morrone (eds.): 491-501. Ediciones Sur. La Plata. Argentina. 
COHEN, R. S. RODRÍGUEZ GIL \& C. G. VÉLEZ. 1999. The post-embryonic development of Artemia persimilis Piccinelli \& Prosdocimi. Hydrobiologia, 391: 63-80. DOI: 10.1023/A:1003567401697

D’AMBRosiO, S., M. C. CLAPS \& A. GARCÍA. 2016. Zooplankton diversity of a protected and vulnerable wetland system in southern South America (Llancanelo area, Argentina). International Aquatic Research, 8: 65-80. DOI: 10.1007/s40071-016-0125-2

DE LOS RÍOS - ESCALANTE, P. 2015. Interaction chilean flamingo (Phoenicopterus chilensis) and zooplanktonic crustaceans: a metacommunity view point. Agriculture \& Forestry, 61 (2): 41-49. DOI: 10.17707/ AgricultForest.61.2.03

DHONT, J. \& P. SORGELOOS. 2002. Applications of Artemia. In: Artemia basic and applied biology. T. Abatzopoulos, J. Beardmore, J. Clegg \& P. Sorgeloos (eds.): 251-277. Kluwer Academic Publishers. Dordrecht. Germany.

DI RIENZO, J. A., F. CASANOVES, $M$. BALZARINI, L. GONZÁLEZ, M. TABLADA. \& C. W. ROBLEDO. 2010. InfoStat (versión 2010). Grupo InfoStat, FCA. Universidad Nacional de Córdoba. Argentina. Accesible at http://www.infostat.com.ar

ECHANIZ, S. A., A. M. VIGNATTI, S. B. JOSÉ DE PAGGI, J. C. PAGGI \& A. PILATI. 2006. Zooplankton seasonal abundance of South American saline shallow lakes. International Review of Hydrobiology, 91 (1): 86-100. DOI: 10.1002/iroh.200510803

ECHANIZ, S. A., G. C. CABRERA \& A. M. VIGNATTI. 2015. Limnological parameters and population structure of Artemia persimilis Piccinelli \& Prosdocimi, 1968 (Crustacea, Anostraca) in La Amarga, a hypersaline lake of La Pampa (Argentina). Research in Zoology, 5 (2): 25- 31. DOI: 10.5923/j.zoology.20150502.01

ECHANIZ, S. A. \& A. M. VIGNATTI. 2017. The zooplankton of the shallow lakes of the semi-arid region of southern South America. Annales de Limnologie - International Journal of Limnology, 53: 345-360. DOI: 10.1051/ $\operatorname{limn} / 2017018$

EPA. 1993. ESS Method 340.2: Total Suspended
Solids, Mass Balance (Dried at $103-105{ }^{\circ} \mathrm{C}$ ) Volatile Suspended Solids (Ignited at $550{ }^{\circ} \mathrm{C}$ ). Environmental Protection Agency (EPA).

GAJARDO, G. M. \& J. BEARDMORE. 2012. The brine shrimp Artemia: adapted to critical life conditions. Frontiers in Physiology, 3: 1-8. DOI: $10.3389 /$ fphys.2012.00185

GIBBS, R. 1970. Mechanisms controlling world water chemistry. Science, 170:1088 -1090.

GONZÁLEZ-ROGLICH, M., D. VILLARREAL \& M. G. CASTRO. 2012. Evaluación de la efectividad de la Reserva Parque Luro como herramienta de conservación del Caldenal pampeano: cambios en la cobertura vegetal a nivel de paisaje entre 1960 y 2004. Ecología Austral, 22: 11-21.

GREEN, A. J., M. I. SÁNCHEZ, F. AMAT, J. FIGUEROLA, F. HONTORIA, O. RUIZ \& F. HORTAS. 2005. Dispersal of invasive and native brine shrimps Artemia (Anostraca) via waterbirds. Limnology and Oceanography, 50(2): 737-742. DOI: 10.4319/lo.2005.50.2.0737

HAMMER, Ø, D. A. HARPER \& P. D. RYAN. 2001. PAST: Paleontological Statistics Software Package for Education and Data Analysis. Palaeontologia Electronica, 4 (1): 1-9.

HAMMER, U. T. 1986. Saline Lake Ecosystems of the World. Monographiae Biologicae 59. Dr. W. Junk Publishers, Dordrecht. Germany. HERBST, D. 2001. Gradients of salinity stress, environmental stability and water chemistry as a templet for defining habitat types and physiological strategies in inland salt waters. Hydrobiologia, 466: 209-219.

KALFF, J. 2002. Limnology. Inland Water System. Prentice Hall. New Jersey. USA.

LORENZO, F., A. MEHL \& M. ZÁRATE. 2013. Sedimentología y estratigrafía de depósitos del mioceno tardío de los valles transversales de la provincia de La Pampa, Argentina. Latin American Journal of Sedimentology and Basin Analysis, 20 (2): 67-84.

MALÁN, J. 2007. Características de las aguas subterráneas y fangos en el área del "Balneario Utracán" - La Pampa. In: Libro de Trabajos del Segundo Congreso Pampeano del Agua. Secretaría de Recursos Hídricos de La Pampa (ed.): 95-104. Gobierno de la Provin- 
cia de La Pampa, Santa Rosa, Argentina.

MECHALY, A. S., P. M. CERVELLINI \& G. A. BAMBILL. 2004. Experiencias preliminares con Artemia persimilis (Crustacea, Anostraca) como potencial alimento vivo en acuicultura. AquaTIC, 21: 1-7.

MECHALY, A. S., S. ANGELETTI, P. DE LOS RÍOS-ESCALANTE \& P. M. CERVELLINI. 2013. A review of the biology and ecology of Artemia persimilis Piccinelli \& Prosdocimi, 1968 (Crustacea: Anostraca) as basis for its management. International Journal of Artemia Biology, 3 (1): 12-19.

MEDINA, G. R., J. GOENAGA, F. HONTORIA, G. COHEN \& F. AMAT. 2007. Effects of temperature and salinity on prereproductive life span and reproductive traits of two species of Artemia (Branchiopoda, Anostraca) from Argentina: Artemia franciscana and A. persimilis. Hydrobiologia, 579: 41-53. DOI: 10. 1007/s10750-006-0361-3

MUÑOZ, J., F. AMAT, A. GREEN, J. FIGUEROLA \& A. GÓMEZ. 2013. Bird migratory flyways influence the phylogeography of the invasive brine shrimp Artemia franciscana in its native American range. PeerJ 1:e200. DOI: $10.7717 /$ peerj.200

MUÑOZ, J., A. GÓMEZ, J. FIGUEROLA, F. AMAT, C. RICO \& A. J. GREEN. 2014. Colonization and dispersal patterns of the invasive American brine shrimp Artemia franciscana (Branchiopoda: Anostraca) in the Mediterranean region. Hydrobiologia, 726: 25-41. DOI: 10.1007/s10750-013-1748-6

OYARZÁBAL, M., J. CLAVIJO, L. OAKLEY, F. BIGANZOLI, P. TOGNETTI, I. BARBERIS, H. MATURO, R. ARAGÓN, P. CAMPANELLO, D. PRADO, M. OESTERHELD \& R. LEÓN. 2018. Unidades de vegetación de la Argentina. Ecología Austral, 28: 040-063. DOI: 10.25260/EA.18.28.1.0.399

PAGGI, J. C. 1997. Moina macrocopa (Straus 1820) (Branchiopoda, Anomopoda) in South America: another case of species introduction? Crustaceana, 70 (8): 886-893. DOI: 10.1163/156854097X00500

PASTORINO, X. I., E. MARSCHOFF \& R. COHEN. 2002. Reproductive and brood cycles of Artemia persimilis Piccinelli \& Pros- docimi from Colorada Chica Lake (Province of La Pampa, República Argentina), under laboratory conditions. Hydrobiologia, 486: 279-288. DOI: 10.1023/A:1021327524434

PILATI, A., M. CASTELLINO \& E. BUCHER. 2016. Nutrient, chlorophyll and zooplankton seasonal variations on the southern coast of a subtropical saline lake (Mar Chiquita, Córdoba, Argentina). Annales de Limnologie - International Journal of Limnology, 52: 263-271. DOI: 10.1051/limn/2016014

POLLA, W. M., V. DI PASQUALE, M. RASUK, I. BARBERIS, M. ROMANO, R. MANZO, J. C. PAGGI, M. FARÍAS, M. CONTRERAS \& M. DEVERCELLI. 2018. Diet and feeding selectivity of the Andean Flamingo Phoenicoparrus andinus and Chilean Flamingo Phoenicopterus chilensis in lowland wintering areas. Wildfowl, 68: 3-29.

ROBERTO, Z. E., G. CASAGRANDE \& E. F. VIGLIZZO. 1994. Lluvias en la Pampa Central. Tendencias y variaciones. Publicación $\mathrm{N}^{\circ}$ 12. Centro Regional La Pampa-San Luis, INTA. Santa Rosa. Argentina.

RODRÍGUEZ-CANCHÉ, L., T. MALDONADO-MONTIEL \& L. CARRILLO-NAVARRO. 2006. Calidad biológica y bioquímica de la población de Artemia (Anostraca: Artemiidae) localizada en las salinas de Real de Salinas, Calkiní, Campeche, México. Revista de Biología Tropical - Internacional Journal of Tropical Biology, 54 (4): 1283-1293.

RUSSIÁN, G., E. AGOSTA \& R. COMPAGNUCCI. 2015. Variaciones en baja frecuencia de la precipitación estacional en la región pampa amarilla y posibles forzantes. Meteorologica, 40 (1): 17-42.

SATO, N. E., J. C. MALLO \& J. L. FENUCCI. 2004. Calidad de los quistes de Artemia persimilis (Piccinelli \& Prosdocimi) (Crustacea: Branchiopoda) de diferentes zonas de Argentina, como alimento en acuicultura. Revista de Biología Marina y Oceanografía, 39: 79-92. DOI: $10.4067 /$ S0718-19572004000200004

SOKAL, R. \& F. ROHLF. 1995. Biometría. Principios y métodos estadísticos en la investigación biológica. Ed. Blume, Barcelona. España.

SORGELOOS, P., P. LAVENS, P. LĖ, W. TACKAERT \& D. VERSICHELE. 1986. Manual 
para el cultivo y uso de Artemia en acuicultura. Programa Cooperativo Gubernamental, FAO-Italia

SPEER, F. W. \&. L. J. WEIDER. 2018. Examining population-specific hatching cues of salinity and light for Artemia franciscana. Hydrobiologia, 805: 391-397. DOI: 10.1007/s10750017-3326-9

VIGLIZZO, E. F. 2010. El agro, el clima y el agua en La Pampa semiárida: revisando paradigmas. Anales de la Academia Nacional de Agronomía y Veterinaria (ANAV) LXIV, 251-267.

VIGNATTI, A. M., G. C. CABRERA \& S. A. ECHANIZ. 2012. Changes in the zooplankton and limnological variables of a temporary hypo-mesosaline wetland of the central region of Argentina during the drying. Pan American Journal of Aquatic Sciences, 7 (2): 93-106.

VIGNATTI, A. M., G. C. CABRERA \& S. A. ECHANIZ. 2013. Distribution and biological aspects of the introduced species Moina macrocopa (Straus, 1820) (Crustacea, Cladocera) in the semi-arid central region of Argentina. Biota
Neotropica, 13 (3): 86-92.

VIGNATTI, A. M., G. C. CABRERA, A. PILATI \& S. A. ECHANIZ. 2014. Biology of Artemia persimilis Piccinelli and Prosdocimi, 1968 (Crustacea Anostraca) at the highest salinities reported for the species under natural conditions. International Journal of Artemia Biology, 4 (1): 38-43.

VIGNATTI, A. M., G. C. CABRERA \& S. A. ECHANIZ. 2017. Population dynamics of the brine shrimp Artemia persimilis Piccinelli \& Prosdocimi, 1968 (Crustacea, Anostraca) in a hypersaline lake of the Central Pampa (Argentina). Biota Neotropica, 17 (3): e20170353. DOI: 10.1590/1676-0611-BN-2017-0353

WETZEL, R. 2001. Limnology. Lake and river ecosystems. Academic Press Elsevier. San Diego. USA.

WURTSBAUGH, W. 1992. Food-web modification by an invertebrate predator in the Great Salt Lake (USA). Oecologia, 89: 168-175. DOI: 10.1007/BF00317215

ZAR, J. H. 1996. Biostatistical analysis. Prentice Hall. New Jersey. USA.

Con el patrocinio de:

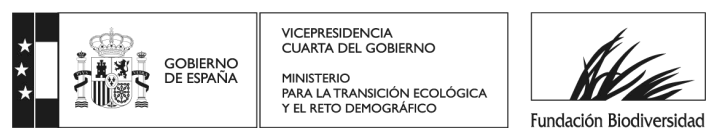

